\title{
Regional and State Associations
}

\section{The Status of Women in Political Science Departments in the Southern Region*}

\section{Committee on the Status of Women, Southern Political Science Association \\ Mary E. Guy, University of Alabama at Birmingham, Chair}

\section{Author's Note: Members of the Committee on the Status of Women of the Southern Political Science Association for 1991 were Pamela Conover, Lois Duke, Patricia Hurley, Kathleen Kemp, Dorothy Stetson, and Martha Swann.}

The purpose of this paper is to report the progress of women in the discipline in the southern region. If these results are a wind sock for progress, then the breeze that is blowing is hardly discernible. The findings show that barriers continue to confront women as they attempt to climb the academic ladder. Two major findings deserve special attention. First, the wash-out rate for women is extraordinarily high: While $47 \%$ of female faculty in political science departments in the South are assistant professors, only $27 \%$ of them are associate professors, and only $26 \%$ are professors. The ordering is in the reverse for men: $26 \%$ of male faculty are assistant professors, $31 \%$ are associate professors, and $43 \%$ are professors. In other words, men enter and continue to climb the academic ladder, while women enter at the assistant level and then disappear rather than continuing up the ladder.

Second, there has been only slight progress in women gaining a toehold in political science departments in recent years. Women comprise $11.1 \%$ of full professors in the southern region in all levels of programs combined, which is the same as national data for all disciplines combined. In the South's doctoral programs, however, women comprise only $5.8 \%$ of faculty who hold the rank of professor.

\section{Background}

At its 1990 Annual Meeting, the Executive Council of the Southern Political Science Association authorized the Committee on the Status of Women (CSW) to conduct a survey of all degree granting political science departments in the southern region. The purpose of this research was to expand the scope of a survey conducted earlier of doctoral granting programs (Stetson, et al. 1990) and to compare regional to national findings. The results provide a means by which the Southern Political Science Association can monitor the status of women in political science departments and by which the Committee on the Status of Women can base recommendations for advancing the integration of women into the discipline. To this end, a survey was conducted in 1991 of all degree granting programs in the southern region. ${ }^{1}$

\section{Results}

The data show that opportunities in political science for women are fewer than those that exist for men. Compared to national data, however, the southern region appears to be similar to the nation as a whole in how it treats women.

\section{Doctoral Programs}

In the previous Committee on the Status of Women survey of doctoral granting programs, which was conducted in late 1988, the findings showed that women held $4.6 \%$ of full professor positions, $10 \%$ of associate professor positions, and $25 \%$ of assistant professor positions. Although the responses to the 1988 survey included 25 institutions and the results in this survey include only 16 doctoral programs, Table 1 shows similar proportions: women hold $5.8 \%$ of the professor positions, $12.9 \%$ of the associate professor positions, and $23 \%$ of the assistant professor positions.

Students and junior faculty bear the brunt of so few women role models. Women comprise $31 \%$ of all students enrolled in Ph.D. programs in political science (American Political Science Association, 1991) but they comprise only $27.4 \%$ of the Ph.D.s granted (Sarkees, McGlen, and Giotto 1991). At least a portion of the attrition for women in doctoral programs and in junior faculty positions can be attributed to the fact that women have limited access to women mentors and role models. The annoyances that accumulate throughout a woman's progression through male-dominated graduate training, male-dominated recruiting, and entry into a male-dominated department combine to accentuate the need for a change of climate,
TABLE 1

Full Time Faculty in Ph.D. Granting Programs: Southern Region

\begin{tabular}{lccccrr}
\hline & \multicolumn{2}{c}{ Male } & & \multicolumn{2}{c}{ Female } & \\
\cline { 2 - 4 } & Number & Percent & & Number & Percent & Total \\
\hline Professor & 113 & 94.2 & 7 & 5.8 & 120 \\
Associate & 74 & 87.1 & & 11 & 12.9 & 85 \\
Assistant & 67 & 77.0 & & 20 & 23.0 & 87 \\
Total $(\mathrm{n}=16)$ & 254 & 87.0 & & 38 & 13.0 & 292 \\
\hline
\end{tabular}


from one of tolerance that views women as worthy projects, to one in which women are full participants.

\section{Master's and Bachelor's Programs}

Table 1 shows the breakdown by rank for faculty in doctoral programs. Tables 2 and 3 show the breakdown by rank for faculty in master's and bachelor's programs. Apparently the opportunities for women increase as the level of the program decreases. A higher percentage of women hold associate and full professor positions in master's degree programs than in doctoral programs. And an even higher percentage of women hold associate and full professor positions in bachelor's programs.

In political science nationally, women comprise $42 \%$ of all students currently enrolled in master's degree programs and they earn $31.3 \%$ of the master's degrees (Sarkees, McGlen, and Giotto 1991). As Table 2 shows, however, the proportion of faculty who are women is not even close to the proportion of women who are students.

Table 3 makes it clear that the opportunities for women faculty are better in bachelor's degree programs than in either master's or doctoral programs.

Lest you fancy that the discipline of political science is more progressive in its behavior toward women than other disciplines, or that the southern region treats women differently than other regions, we include Table 4. Across the nation, in all disciplines in all schools, the percentage of women faculty who are full professors is $11.1 \%$. Judging from this survey, that is precisely the same as the percentage of women who are full professors in the political science programs in the southern region.

To show how limited women's opportunities are in political science, consider for a moment the number of women college presidents that you can name. In terms of proportions, the percentage of women who are full professors is strikingly similar to the proportion of college presidents who are women. It is likely that the average faculty member can name very few women college presidents, although that same faculty member can be expected to know a few in his or her region. The paucity of women in high administrative positions is similar to the paucity of women in faculty positions. Consider what it is like to be a female graduate student or even assistant professor who is trying to find a senior female faculty member as a mentor. They are very few and far between. Their absence contributes to the continued problems that women encounter as they try to gain a toehold in the academy. The problems confronted by women in political science can best be summed up by borrowing Rosabeth Moss Kanter's (1977) conceptualization of opportunity, power, and numbers, which are three significant features that differentiate men from women in the workplace. Low opportunity, low power, and low numerical representation erect structural barriers. People low in career opportunity behave differently than people high in career opportunity. Opportunity relates to expectations and future prospects for mobility and growth. Those with high opportunity

TABLE 2

Full Time Faculty at M.A. Granting Programs: Southern Region

\begin{tabular}{lcccccr}
\hline & \multicolumn{2}{c}{ Male } & & \multicolumn{2}{c}{ Female } & \\
\cline { 2 - 4 } & Number & Percent & & Number & Percent & Total \\
\hline Professor & 108 & 88.5 & & 14 & 11.5 & 122 \\
Associate & 85 & 85.0 & & 15 & 15.0 & 100 \\
Assistant & 59 & 67.8 & & 28 & 32.2 & 87 \\
Total $(n=29)$ & 252 & 81.5 & & 57 & 18.5 & 309 \\
\hline
\end{tabular}

TABLE 3

Full Time Faculty at B.A. Granting Programs: Southern Region

\begin{tabular}{|c|c|c|c|c|c|}
\hline & \multicolumn{2}{|c|}{ Male } & \multicolumn{2}{|c|}{ Female } & \multirow[b]{2}{*}{ Total } \\
\hline & Number & Percent & Number & Percent & \\
\hline Professor & 68 & 83.9 & 13 & 16.1 & 81 \\
\hline Associate & 38 & 79.2 & 10 & 20.8 & 48 \\
\hline Assistant & 41 & 74.5 & 14 & 25.5 & 55 \\
\hline Total $(n=44)$ & 147 & 79.9 & 37 & 20.1 & 184 \\
\hline
\end{tabular}

\section{TABLE 4}

Full Time Faculty in Degree Granting Programs: Southern Region

\begin{tabular}{|c|c|c|c|c|c|}
\hline & \multicolumn{2}{|c|}{ Male } & \multicolumn{2}{|c|}{ Female } & \multirow[b]{2}{*}{ Total } \\
\hline & Number & Percent & Number & Percent & \\
\hline Professor & 281 & 88.9 & 35 & 11.1 & 316 \\
\hline Associate & 198 & 84.6 & 36 & 15.4 & 234 \\
\hline Assistant & 169 & 73.2 & 62 & 26.8 & 231 \\
\hline Total $(n=89)$ & 648 & 83.0 & 133 & 17.0 & 781 \\
\hline
\end{tabular}

\section{TABLE 5}

Women Unequal to Men on College Campuses*

\begin{tabular}{llc}
\hline & Women & Men \\
\hline Student Government Presidents & $24.5 \%$ & $75.5 \%$ \\
Tenured Full Professors & $11.1 \%$ & $88.9 \%$ \\
College University Presidents & $10.3 \%$ & $89.7 \%$ \\
Boards of Trustees & $20.1 \%$ & $79.9 \%$ \\
\hline
\end{tabular}

"Source: National Women's Studies Association, “Inequality on College Campuses,"

NWSAction Newsletter, University of Maryland, College Park, Maryland, 2:1, 1989, p. 11. 
have high aspirations, are competitive, and are more committed to the organization and to their careers. They value their competence, and become impatient or disaffected if they do not keep moving. On the other hand, those in low opportunity positions limit their aspirations, seek satisfaction in activities outside of work and have a horizontal orientation rather than a vertical orientation. They find ways to create a sense of efficacy and worth through personal relationships, they resign themselves to staying put, and they are concerned with basic survival and extrinsic rewards.

Power is the capacity to mobilize resources. People low in organizational power tend to foster lower group morale, behave in more directive, authoritarian ways, use coercive rather than persuasive power, and are more insecure. They are more controlling and more critical. People high in organizational power foster higher group morale, behave in less rigid, directive, authoritarian ways, and delegate more control. They allow subordinates more latitude and discretion and are more often seen as helping rather than hindering.

Numbers relates to the composition of people in approximately the same situation. It is a numerical matter of how many people of a kind are present, so that differentness is, or is not, noticeable. People whose type is represented in very small proportion tend to be more visible, that is, they are "on display." They feel more pressure to conform and to make fewer mistakes, they find it harder to gain credibility, they are more isolated and peripheral, and they are more likely to be excluded from informal peer networks. Thus, they are limited in their source of power-through-alliance. Furthermore, they face more personal stress, are stereotyped, and are placed in role traps that limit effectiveness. People whose type is represented in very high proportion tend to "fit in," are preferred for high communication jobs, and find it easier to gain credibility in positions beset by high uncertainty. They are more likely to be accepted into the informal network, to form peer alliances, and to learn the ropes from peers. They are also more likely to be sponsored by higher status organization members and to acquire mentors easily.

These three possessions-opportunity, power, and numbers-combine to produce self-perpetuating cycles. Thus, those with high opportunity behave in ways that generate more opportunity, which in turn produces further inducement for the behavior. High opportuity is accompanied by more power. Both opportunity and power coincide with being a member of a group that constitutes a large enough proportion of the workforce so that any one member of the group is not immediately noticeable as "different." The confluence of opportunity, power, and numbers then produces upward cycles of advantage or downward cycles of disadvantage. The cycle of high opportunity, power, and numbers makes it very difficult for newcomers (such as women) to break into the academy. The cycle of low opportunity, powerlessness, and tokenism is also difficult to break because of its self-perpetuating nature. Other than the occasional individual who is fortunate enough to escape its grasp, the cycle can only be broken by intervention in the form of structural change.

\section{Compression of Women Faculty at Lower Ranks}

There is a compression in the percentage of women political scientists at the lower rungs of the academic ladder. Sarkees, McGlen and Giotto (1991) report that there has been only a barely noticeable increase in the percentage of full professors who are women over the past 20 years. Data from $1989-90$ show that only $7.6 \%$ of all full professors are women. Growth in the other ranks has been more marked. They report that the percentage of associate professors who are women doubled from $8.1 \%$ to $16.2 \%$ between 1972 and 1989 , while the percentage of women at the assistant professor rank increased nearly three-fold. Table 6 shows that the compression is as real in the southern region as it is nationally. The table shows the relationship between rank and type of program for full-time faculty.

It is naive to assume that the results shown in these tables reflect the fact that women do not engage in scholarly research and do not jump through the necessary hoops of academic life. For example, Sarkees, McGlen, and Giotto (1991) report

\section{TABLE 6}

Distribution of Faculty Across Ranks by Program Type

\begin{tabular}{|c|c|c|}
\hline & $\begin{array}{c}\text { Women Faculty } \\
\%\end{array}$ & $\begin{array}{c}\text { Men Faculty } \\
\%\end{array}$ \\
\hline \multicolumn{3}{|l|}{ Doctoral Programs } \\
\hline Professor & 18 & 44 \\
\hline Associate Professor & 29 & 29 \\
\hline \multirow[t]{2}{*}{ Assistant Professor } & 53 & 26 \\
\hline & 100 & 100 \\
\hline \multicolumn{3}{|l|}{ Master's Programs } \\
\hline Professor & 25 & 43 \\
\hline Associate Professor & 26 & 34 \\
\hline \multirow[t]{2}{*}{ Assistant Professor } & 49 & 23 \\
\hline & 100 & 100 \\
\hline \multicolumn{3}{|l|}{ Bachelor's Programs } \\
\hline Professor & 35 & 46 \\
\hline Associate Professor & 27 & 26 \\
\hline \multirow[t]{2}{*}{ Assistant Professor } & 38 & 28 \\
\hline & 100 & 100 \\
\hline \multicolumn{3}{|l|}{ All } \\
\hline Professor & 26 & 43 \\
\hline Associate Professor & 27 & 31 \\
\hline \multirow[t]{2}{*}{ Assistant Professor } & 47 & 26 \\
\hline & 100 & 100 \\
\hline
\end{tabular}


that more than $23 \%$ of APSA's membership are women. And, they report that at APSA's 1990 annual meeting, $22 \%$ of the panel chairs were women, $24 \%$ of paper givers were women, and $24 \%$ of the discussants were women. This indicates a level of participation that is quite high, given the constraints on travel funds and the fact that many active researchers do not travel to the APSA Annual Meeting.

An October 9, 1991, article in the Chronicle of Higher Education reports that the problems of 20 years ago still face women today. "Although the number of female professors in the country has increased since the early 1970s, their proportion of the total faculty has remained relatively steady" (Blum 1991, A20). What increases that have occurred have occurred in the assistant professor ranks, which are about $38 \%$ in 1989 while they were $24 \%$ in 1972. Blum reminds the reader that it costs a lot of money to recruit faculty members and to keep losing them because of an unwillingness to change practices and policies that advantage men but disadvantage women does not make good business sense.

\section{Summary}

The comments of one respondent sum up the results of this survey: "To me it is obvious that the only women and/or minorities that my department will agree to hire are those they feel not threatened by and superior to. Whoever is hired has to acquiesce to the males in order to get hired, get merit pay, get tenure and get promoted. I have seen a female tenured faculty rushed into retirement, and four others hired and leave due to all kinds of pressures and criticisms." This is the result of women having low opportunity, low power, and low numbers.

Daphne Patai (1991) frames the problem of minority status as being one of having "surplus visibility." She explains an important aspect of this phenomenon: "The first concerns the shift that occurs in public perceptions as traditionally powerless and marginalized groups challenge the expectation that they should be invisible and silent. For those who long have been in positions of dominance, any space that minorities occupy appears excessive and the voices they raise sound loud and offensive" (p. A52). Thus, surplus visibility assures that when "one of them" is visible at all, all "of them" are seen to be taking over and are seen as a threat to the status quo. There is no middle ground that women can inhabit. They are forced to choose between invisibility and surplus visibility, between silence and the accusation that they are making excessive noise. She explains, "the very ascription of minority status confines one to a limited area of action, a constricted space with few choices. One can either stay in line and try to escape notice, which means colluding in one's own invisibility, or one can do something and thereby become the victim of surplus visibility.

Women are different from men. The fact that women may pursue areas of research that men prefer not to investigate, such as women and politics, does not mean that their research disqualifies them from holding a seat in a political science department. And the fact that publication outlets for new lines of research are not to be found in the traditional outlets should not disqualify women from holding a seat in a political science department. This is what it means to acknowledge and tolerate diversity: accepting that there are different routes to the truth, that yours may not be hers."

\section{Recommendations}

The purpose of the Committee on the Status of Women is to keep the status of women in political science in everyone's awareness and work toward improving it. To that end, the Committee makes the following recommendations:

1. The SPSA should charge the Committee on the Status of Women with the responsibility of monitoring the rate of women's integration into the discipline, of embarking on a study of career paths of women in the discipline, and of reporting to the Association annually. The reports of the Committee should be distributed to all political science departments in the region.
2. The SPSA should actively encourage political science departments

(a) to institute structural changes to tenure policies to provide for women faculty who must proceed slower on their research agenda than their male peers because of pregnancy and child care responsibilities. One option is to allow the faculty member to elect one additional year in the tenure time-line.

(b) to hire enough female faculty to provide female (and male) students with mentors and role models; women can help other women anticipate the sorts of career roadblocks that men do not experience.

(c) to understand that diversity means "differentness," and that to accept diversity means to broaden your scope of what avenues of research are legitimate fields of inquiry; then reward good research, even though it is "different" from what you have always done.

(d) to understand that some of the concerns which women faculty and students express may be different from those customarily expressed by men. Complaints of sexual harassment are an example. This, again, is what diversity is all about. Just because something is different does not mean that it is lesser. Women are neither "special projects" nor "complaining nuisances." They are legitimate people with legitimate concerns.

(e) to remember that, when it comes to hiring, it is easier "to get one" after you already "have one." So when interviewing a woman candidate, be sure to include visits with other female faculty during her campus visit.

(f) to help address the problem of dual career couples in which a position is available for one member but not for the spouse, try to institute a low-cost offering such as a visiting professor status that entails no salary but perhaps a computer account, mailbox, and stationery.

(g) to pay attention to the connection between the recruiting process and tenure and promotion standards. When departments hire a woman, just to hire a woman, they do no one a favor. To hire someone whose record already shows a lack of requisite skills is to set up a situation where you will be saying several years hence "We had one but she 
didn't work out."

(h) to be sure that service responsibilities are spread equally around faculty, rather than burdening women with a disproportionately high share of assignments (if for no other reason than to show her off and prove "that you have one").

\section{Notes}

\begin{abstract}
*Final report presented to the Executive Council of the Southern Political Science Association, Tampa, Florida, November 7 , 1991

1. The questionnaire used for the earlier survey of doctoral degree granting political science departments (Stetson, et al. 1990) was adapted for this survey. A cover letter signed by Bradley Canon, 1991 President of SPSA, and Mary Guy, CSW Chair, accompanied the questionnaire. Mailing labels were secured from the American Political Science Association office. The mailings to departments were made by SPSA Executive Director Michael Maggiotto. All bachelor's, master's, and doctoral degree-granting political science programs in Florida, Georgia, South Carolina, North Carolina, Virginia, Maryland, West Virginia, Kentucky, Tennessee, Alabma, Mississippi, Louisiana, Texas, Arkansas, District of Columbia, and Delaware were surveyed. There were 92 returned surveys out of 412 that had been mailed, yielding a response rate of $22 \%$. Of the returned surveys, 89 had been completed and were included in the tally of results. The response rate may have been depressed by the fact that the survey was conducted during the summer months and no attempt was made to contact departments that did not respond.
\end{abstract}

\section{References}

American Political Science Association. 1991. Graduate Students and Faculty in Political Science Ph.D. and M.A. Programs 1991. Report available from APSA, 1527 New Hampshire Avenue, N.W., Washington, DC 20036.

Blum, Debra E. 1991. "Environment Still Hostile to Women in Academe, New Evidence Indicates." The Chronicle of Higher Education (October 9): A1, A20.

Kanter, Rosabeth Moss. 1977. Men and Women of the Corporation. New York: Basic.

Patai, Daphne. 1991. "Minority Status and the Stigma of 'Surplus Visibility.' " The Chronicle of Higher Education (October 30): A52.

Sarkees, Meredith R., Nancy E. McGlen, and Valerie Giotto. 1991. "Women in Political Science: On and Off the Tenure Track." Paper presented at the annual meeting of the American Political Science Association, Washington, DC.

Stetson, Dorothy M., Diane Wall, Mary E. Guy, Erika Fairchild, David Canon, and C. Brown. 1990. "The Status of Women in Ph.D. Departments." PS: Political Science \& Politics (March): 82-86.

\section{New England Political Science Association}

The New England Political Science Association held its 1992 annual meeting in Providence, Rhode Island on April 3 and 4. The meeting, attended by almost two hundred scholars from around the nation, was organized by Association President Garrison Nelson, University of Vermont, and Program Chair Eileen McDonagh, Northeastern University. Current officers of the Association include President Deborah Miner, Simmons College, and President-Elect Harvey Mansfield, Jr., Harvard University. Highlights of the 1992 meeting included luncheon talks by Rep. Bernard Sanders (D-VT) and Alan Ehrenhalt, editor of Governing, and a plenary session marked by a debate between Madeline Kunin, former governor of Vermont, and former APSA President Theodore Lowi. The Donovan Prize for the best paper presented at the 1991 meeting was awarded to Mark E. Warren, of Georgetown University, for "Max Weber's Nietzschean Conception of Power," while the prize for the best paper offered by a graduate student at the 1991 meeting went to Robert J. Weiner, Cornell University, for "Making History in Vermont: The Election of Bernard Sanders to the U.S. Congress."

The association's 1993 annual meeting will be held on Friday, April 2 and Saturday, April 3, in Northampton, Massachusetts. Proposals should be submitted by December 1, 1992, and can be directed to the 1993 Program Chair, Christopher J. Bosso, Department of Political Science, 315 Meserve Hall, Northeastern University, Boston, MA 02115. Phone: (617) 437-4398.

\section{A Brief Look at $50+$ Years of Scholarly Development in the Midwest Political Science Association}

\author{
John P. Pelissero and \\ Timothy B. Krebs \\ Midwest Political Science Association
}

On May 5, 1939 a Conference of Midwest Political Scientists was held at Turkey Run State Park in Indiana. Organized by Clarence Berdahl, Gale Lowrie, James Pollock, Jr., and Harold Zink, the participants spent a day and a half discussing the problems of teaching political science, U.S. foreign policy, the Republican revival in the Midwest, public administration and colleges, and the "possibilities of a Mid-West Association of Political Scientists." The group collected $\$ 29.50$ in contributions and spent $\$ 21.45$ on the conference. That first program had just 21 people on the official panels (no unaffiliated groups had formed as yet) and filled only two small pages. So began what would later be called the Midwest Political Science Association.

The second conference, "Turkey Run II," organized by Charles Kneier (Illinois), was held at the same state park and began on May 3, 1940 at 2:30 P.M. (C.S.T.) (apparently Indiana was on "God's time" even back then) and included only 19 participants on four panels. The assembled again dealt with the "Problems of Teaching Political Science," confronted the "emerging issues of American Politics in the International Field," obtained their first exhibitor, and held their first business meeting. Estimated attendance at the meeting was 125 (35 individuals "snuck-in" to avoid paying the 50-cent registration fee (a practice that continues today!). Secretary-Treasurer Harold Zink noted that 110 attended one panel (could we ever expect 88 percent to attend a single panel today?).

The decision to leave Turkey Run after two years was not an easy one for the fledgling association. The Managerial Committee met in Chicago in December, 1940 and the minutes report that:

After considerable discussion it was decided to hold the 1941 conference at Pokagon State Park, Indiana if suitable arrangements can be made. Carl Smith was appointed to ascertain whether such arrangements can be made at Pokagon Park. Spring Mill State Park was agreed upon as second choice in case Pokagon did not work out.

Inasmuch as the place of holding the 1941 conference is located some- 